\title{
Can clonidine, enoximone, and enalaprilat help to protect the myocardium against ischaemia in cardiac surgery?
}

Joachim Boldt, Gabriele Rothe, Ehrenfied Schindler, Carsten Döll, Gerold Görlach, Gunter Hempelmann

\begin{abstract}
Objective-To evaluate whether clonidine, enoximone, and enalaprilat reduce ischaemia-related myocardial cell damage in cardiac surgery.

Design-Prospective randomised controlled trial.

Setting-Clinical investigation in a cardiac anaesthesia department of a university hospital.

Patients -88 consecutive patients undergoing coronary artery bypass surgery.

Interventions-After induction of anaesthesia patients continuously received the $\alpha_{2}$ agonist clonidine (group $1, \mathbf{n}=22$ ), the phosphodiesterase (PDE) III inhibitor enoximone (group $2, \quad n=22$ ), the angiotensin converting enzyme (ACE) inhibitor enalaprilat (group $3, n=22$ ), or saline solution as placebo ( control group, $n=22$ ). The infusion was stopped immediately before the start of cardiopulmonary bypass.
\end{abstract}

Main outcome measures-The ST segment was analysed and the activity of creatine kinase isoenzyme MB (CKMB), cardiac troponin $T$ ( $T n T)$, and the BB isoenzyme of glycogen phosphorylase (GPBB) were measured before the start of infusion (baseline), after weaning from cardiopulmonary bypass (CPB), at the end of surgery, $5 \mathrm{~h}$ after CPB, and on the morning of the first and third postoperative days.

Results-Biometric data and time of cross-clamping were not significantly different in the four groups. Changes in the ST segment indicating ischaemia were least common in the enalaprilat group (P $<0.05)$. Postoperatively, CKMB activity was significantly higher in the clonidine and the control groups. Both new markers of myocardial cell damage increased more after CPB and postoperatively in the control patients (TnT peak: (mean (SD)) $3.99(0.35) \mu \mathrm{g} / 1$; GPBB peak: 82 (15) $\mathrm{ng} / \mathrm{ml}$ ) and the clonidine-treated group (TnT peak: $3.80(0 \cdot 3) \mu g / 1 ;$ GPBB peak: 85 (14) $\mathrm{ng} / \mathrm{ml}$ ). Enalaprilat-treated patients showed the smallest overall changes in standard (CKMB) and new serological markers of myocardial ischaemia (TnT peak: $0.71 \quad(0.1) \mu \mathrm{g} / 1$; GPBB peak: 44 (14) ng/ml).

Conclusions-In patients treated with enalaprilat before CPB, both new, more sensitive markers of ischaemic myocardial tissue damage increased significantly less than in an untreated control group. Those treated with enoximone also had lower plasma concentration of $\mathrm{TnT}$ and GPBB than the control group, whereas clonidine did not reduce the concentration of these markers of myocardial ischaemia. Pharmacological interventions, such as the continuous infusion of the ACE inhibitor enalaprilat, before start of CPB may help to protect the heart against ischaemia/reperfusion injury.

(Heart 1996;76:207-213)

Keywords: ischaemic markers, myocardial preservation, myocardial tissue damage, surgery.

Patients undergoing coronary artery bypass grafting (CABG) are at risk of myocardial cell injury. ${ }^{1}$ Detection of ischaemia in these patients is difficult. ${ }^{2}$ Standard indices such as the electrocardiogram or creatine kinase $\mathrm{MB}$ were not sensitive and specific enough to detect minor ischaemia-related myocardial tissue damage. ${ }^{3}$ Standard laboratory variables, such as the activity of the creatine kinase isoenzyme $\mathrm{MB}$ (CKMB), have been shown to be a serological marker for more extensive ischaemic myocardial cell injury. CKMB release from skeletal muscle after surgery, however, can also increase plasma CKMB.

In recent years, new markers of myocardial ischaemia have been used to assess the degree of myocardial tissue damage. Cardiac troponin $\mathrm{T}(\mathrm{TnT})$ is $100 \%$ cardiospecific. $\mathrm{TnT}$ was demonstrated to be more sensitive to and specific for myocardial tissue damage secondary to angina or infarction than commonly used serological markers of ischaemia. ${ }^{47} \mathrm{TnT}$ was found to have a sensitivity of $98 \%$ and a specificity of $98 \%$ or even $100 \% .^{8}$ By contrast, the sensitivity of CKMB was found to be only $84 \%$ and specificity was $98 \% .{ }^{9}$ Thus TnT is believed to be superior to CKMB activity in the diagnosis of minor myocardial cell damage.

The isoenzyme BB of glycogen phosphorylase (GPBB) is another promising method for detecting ischaemic myocardial cell damage more precisely. Glycogen phosphorylase is the key enzyme of glycogenolysis. There are three major isoenzymes of GP: one is detected in the brain (BB) and is also found in human myocardium, a second is detected in muscle (MM), and a third is found in the liver (LL). ${ }^{10}$ GPBB in the myocardium is associated with glycogen and the sarcoplasmatic reticulum.

\author{
Accepted for publication \\ 13 February 1996 \\ Professor J Boldt \\ Apartment of \\ Intensive Care Medicine \\ Ludwigshafen, \\ Bremserstrasse 79, 67063 \\ Ludwigshafen am Rhein,
}


This macromolecular complex (sarcoplasmic reticulum-glycogenolysis complex) is broken down during ischaemia ${ }^{11}$ and GPBB is released into the sarcoplasm. Myocardial ischaemia results in glycogenolysis and (transient) alterations in plasma membrane integrity. During myocardial ischaemia GPBB is released into the circulation from (ischaemically) injured myocardial tissue. ${ }^{12} 13$ This increase in circulating GPBB seems to peak earlier than standard (CKMB) or newer (for example, TnT) markers of myocardial damage. ${ }^{10}$

Several pharmacological approaches have been used to reduce the incidence of perioperative myocardial ischaemia in cardiac surgery. Less ischaemia and/or improved myocardial function have been reported after treatment with glyceryl trinitrate, ${ }^{14}$ the $\mathrm{Ca}^{++}$channel blocker nifedipine, ${ }^{15}$ and acadesine. ${ }^{16}$ Promising results were also reported with the centrally acting $\alpha_{2}$ adrenoceptor agonist clonidine $^{17}$, the phosphodiesterase (PDE)-III inhibitor enoximone, ${ }^{18}$ and angiotensin converting enzyme (ACE) inhibitors (for example, enalaprilat ${ }^{19}$ ). Most studies, however, were based on monitoring the electrocardiogram and systemic haemodynamics or were carried out in an experimental setting. Data on the cardioprotective effects of clonidine, enalaprilat, and enoximone during cardiac surgery have not yet been evaluated precisely. Thus the present study was designed to investigate whether intraoperative treatment with these drugs reduced ischaemia-related myocardial cell damage in patients undergoing coronary artery surgery.

\section{Patients and methods}

STUDY GROUPS

We studied 88 patients undergoing elective first time coronary artery bypass grafting (CABG). The study was approved by the ethics study committee and informed consent was obtained from all patients. Exclusion criteria were renal insufficiency (serum creatinine

Table 1 Patients' characteristics and data from perioperative period

\begin{tabular}{|c|c|c|c|c|}
\hline Variable & Clonidine & Enoximone & Enalaprilat & Control \\
\hline $\begin{array}{l}\text { Age (yr) } \\
\text { Weight (kg) }\end{array}$ & $\begin{array}{l}64 \cdot 2(4 \cdot 9) \\
76 \cdot 4(7 \cdot 9)\end{array}$ & $\begin{array}{l}64 \cdot 9(5 \cdot 1) \\
78 \cdot 3(4 \cdot 8)\end{array}$ & $\begin{array}{l}63 \cdot 2(6 \cdot 6) \\
77 \cdot 7(8 \cdot 9)\end{array}$ & $\begin{array}{l}62 \cdot 9(6 \cdot 0) \\
77 \cdot 1(6 \cdot 4)\end{array}$ \\
\hline $\begin{array}{l}\text { Preoperative medication: } \\
\text { Glyceryl trinitrate } \\
\beta \text {-blockers } \\
\mathrm{Ca}^{++} \text {channel blockers }\end{array}$ & $\begin{array}{r}\text { All } \\
7 \\
7\end{array}$ & $\begin{array}{r}\text { All } \\
7 \\
8\end{array}$ & $\begin{array}{r}\text { All } \\
6 \\
9\end{array}$ & $\begin{array}{r}\text { All } \\
6 \\
8\end{array}$ \\
\hline $\begin{array}{l}\text { LVEF (\%) } \\
\text { LVEDP (mmHg) }\end{array}$ & $\begin{array}{l}60 \cdot 7(4 \cdot 6) \\
17 \cdot 2(3 \cdot 9)\end{array}$ & $\begin{array}{l}62 \cdot 2(5 \cdot 4) \\
16 \cdot 7(4 \cdot 3)\end{array}$ & $\begin{array}{l}61 \cdot 1(5 \cdot 1) \\
17 \cdot 4(4 \cdot 3)\end{array}$ & $\begin{array}{l}60 \cdot 9(5 \cdot 0) \\
18 \cdot 0(4 \cdot 1)\end{array}$ \\
\hline Total amount of drug & $307(26) \mu \mathrm{g}$ & $29 \cdot 5(3 \cdot 7) \mathrm{mg}$ & $3.3(0.3) \mathrm{mg}$ & - \\
\hline $\begin{array}{l}\text { CPB time (min) } \\
\text { Ischaemia (min) }\end{array}$ & $\begin{array}{r}115 \cdot 5(20 \cdot 3) \\
71 \cdot 2(11 \cdot 1)\end{array}$ & $\begin{aligned} & 114 \cdot 3(23 \cdot 1) \\
& 69 \cdot 2(9 \cdot 7)\end{aligned}$ & $\begin{array}{r}111.5(22 \cdot 0) \\
69 \cdot 2(12 \cdot 8)\end{array}$ & $\begin{array}{r}110 \cdot 9(19 \cdot 9) \\
70 \cdot 2(9 \cdot 8)\end{array}$ \\
\hline $\begin{array}{l}\text { Bypass grafts: } \\
\text { Mammary artery graft } \\
\text { Vein grafts }\end{array}$ & $\begin{array}{l}\text { All } \\
2.9(0.2)\end{array}$ & $\begin{array}{l}\text { All } \\
2 \cdot 6(0 \cdot 3)\end{array}$ & All $_{2 \cdot 6(0.5)}$ & $\mathrm{All}_{2 \cdot 7(0.4)}$ \\
\hline $\begin{array}{l}\text { Pacing during weaning } \\
\text { from CPB (no. of patients) }\end{array}$ & $9^{\star}$ & 3 & 2 & 4 \\
\hline $\begin{array}{l}\text { Myocardial infarction after } \\
\text { CPB (no. of patients) }\end{array}$ & 2 & - & - & 2 \\
\hline Stay in hospital & $11 \cdot 0(2 \cdot 9)$ & $8 \cdot 7(2 \cdot 0)$ & $8 \cdot 0(2 \cdot 7)$ & $10 \cdot 1(3 \cdot 3)$ \\
\hline
\end{tabular}

LVEF, preoperative left ventricular ejection fraction; LVEDP, preoperative left ventricular end diastolic pressure; CPB, cardiopulmonary bypass; ischaemia, period of aortic cross clamping; ${ }_{\star} \mathrm{P}<0.05$ different versus the other three groups.
$>1.5 \mathrm{mg} / \mathrm{dl}$ ), unstable angina, left ventricular ejection fraction (LVEF) $<40 \%$, left ventricular end diastolic pressure (LVEDP) $>25 \mathrm{~mm}$ $\mathrm{Hg}$, and a mean arterial blood pressure (MAP) $<70 \mathrm{~mm} \mathrm{Hg}$ in a haemodynamically steady state after induction of anaesthesia. Except for aspirin, preoperative medication was continued until the morning of the operation (table 1).

Preoperatively, the patients were allocated randomly to continuous intravenous infusion of one of the following: group $1(n=22)$ clonidine $\left(0.05 \mu \mathrm{g} \cdot \mathrm{kg}^{-1} \cdot \mathrm{min}^{-1}\right)$; group $2(\mathrm{n}=$ 22) enoximone $\left(5 \mu \mathrm{g} \cdot \mathrm{kg}^{-1} \cdot \mathrm{min}^{-1}\right)$; group 3 (n $=22$ ) enalaprilat $\left(0.6 \mu \mathrm{g} \cdot \mathrm{kg}^{-1} \cdot \mathrm{min}^{-1}\right)$; group $4(n=22)$ saline solution given as placebo (control patients). The infusion was started after induction of anaesthesia and was continued until the start of CPB.

ANAESTHESIA AND CARDIOPULMONARY BYPASS Anaesthesia was induced with midazolam $(0.15 \mathrm{mg} / \mathrm{kg})$, fentanyl $(5 \mu \mathrm{g} / \mathrm{kg})$, and pancuronium $(0.1 \mathrm{mg} / \mathrm{kg})$ and maintained by weight-related doses of these agents. The entire procedure of anaesthesia, documentation, and analyses of all data were carried out by anaesthesiologists not involved in the study and blinded to the patient's study group.

Before the start of CPB, $300 \mathrm{U} / \mathrm{kg}$ of bovine heparin was given to achieve anticoagulation (activated clotting time $>400$ s). CPB was performed with a non-pulsatile pump and membrane oxygenators (Sorin 41, Sorin, Turin, Italy). The circuit was primed with $1000 \mathrm{ml}$ of $5 \%$ dextrose solution, $1000 \mathrm{ml}$ of Ringer's solution, and $250 \mathrm{ml}$ of $5 \%$ albumin. A flow of $2.41 \mathrm{~min}^{-1} \cdot \mathrm{m}^{-2}$ was used and the temperature was kept between $33^{\circ} \mathrm{C}$ and $34^{\circ} \mathrm{C}$. For myocardial protection, $1000 \mathrm{ml}$ of Bretschneider's cardioplegic solution (low sodium (15 mmol/1), no calcium, containing mannitol $(20 \mathrm{mmol} / \mathrm{l})$, and buffered with histidine $(180 \mathrm{mmol} / \mathrm{l})$ ) was given over $5 \mathrm{~min}$ by gravity followed by a $200 \mathrm{ml}$ reinfusion after $30 \mathrm{~min}$. Topical myocardial cooling was extensively performed during infusion of cardioplegia by rinsing cold saline solution over the surface of the heart. Within 20 min after the start of CPB, blood in the extracorporeal circuit was concentrated using an ultrafiltration device (haemofilter HF-80, Fresenius, Bad Homburg, Germany) to keep haemoglobin between 8 and $9 \mathrm{~g} / \mathrm{dl}$. When necessary, Ringer's solution or packed red blood cells (PRBC) (when haemoglobin was $<8 \mathrm{~g} / \mathrm{dl}$ ) was added to the circuit to maintain the filling volume of the reservoir. During separation from bypass, as much pump blood as was necessary to keep pulmonary capillary wedge pressure (PCWP) $>10 \mathrm{Hg} \mathrm{mmg}$ but $<12 \mathrm{~mm} \mathrm{Hg}$ was infused. After CPB ended, the residual blood of the extracorporeal oxygenation equipment was concentrated using the HF-system, and the autologous blood was retransfused until the end of the operation. Protamine sulphate was given to antagonise the heparin (1:1 ratio) that had been given initially. All patients were operated upon by the same surgical team blinded to the treatment group. 
Table 2 Treatment during weaning from cardiopulmonary bypass (CPB) until the end of surgery

\begin{tabular}{|c|c|c|c|c|}
\hline & Clonidine & Enoximone & Enalaprilat & Control \\
\hline \multicolumn{5}{|l|}{ Adrenaline: } \\
\hline Patients (n) & 4 & - & 1 & 4 \\
\hline Dose $(\mu \mathrm{g} / \mathrm{min})$ & $3-15$ & - & 5 & $2-7$ \\
\hline \multicolumn{5}{|l|}{ Dobutamine: } \\
\hline Patients (n) & 2 & - & - & 1 \\
\hline Dose $(\mu \mathrm{g} / \mathrm{min})$ & $240-480$ & - & - & 480 \\
\hline \multicolumn{5}{|l|}{ Noradrenaline: } \\
\hline Patients (n) & 1 & 1 & 1 & 1 \\
\hline Dose $(\mu \mathrm{g} / \mathrm{min})$ & 5 & 5 & 4 & 5 \\
\hline \multicolumn{5}{|l|}{ Glyceryl trinitrate: } \\
\hline Patients (n) & $6^{\star}$ & 1 & 2 & 5 \\
\hline Dose $(\mu \mathrm{g} / \mathrm{min})$ & $30-75$ & $30-60$ & $30-45$ & $15-60$ \\
\hline \multicolumn{5}{|l|}{ Nifedipine: } \\
\hline Patients (n) & 4 & 2 & - & 3 \\
\hline Dose $(\mu \mathrm{g} / \mathrm{min})$ & $8-20$ & $5-15$ & - & $8-20$ \\
\hline
\end{tabular}

*Significant $(\mathrm{P}<0.05)$ difference compared with the other treated groups.

Table 3 Changes in ST-segment indicating myocardial ischaemia (number of patients)

\begin{tabular}{lllll}
\hline & Clonidine & Enoximone & Enalaprilat & Control \\
\hline After CPB & $6^{\star}$ & 1 & - & 5 \\
End of surgery & 3 & 2 & - & 5 \\
5 h after CPB & 4 & 1 & - & 3 \\
1st PO day & 3 & - & - & 1 \\
3rd PO day & 2 & - & 1
\end{tabular}

CPB, cardiopulmonary bypass; ${ }^{\star} \mathrm{P}<0.05$ compared with the other treated groups. PO, postoperative day.

Postoperatively, filling pressures (PCWP, central venous pressure (CVP)) were maintained between 12 and $15 \mathrm{~mm} \mathrm{Hg}$ by infusion of PRBC (when haemoglobin was less than 9 g/dl) or Ringer's solution and low molecular weight (LMW) hydroxyethyl starch (HES) solution. To guarantee adequate haemodynamic function (MAP $>60 \mathrm{~mm} \mathrm{Hg}$, CI $>2.251 \mathrm{~min}^{-1} \cdot \mathrm{m}^{-2}$, systemic vascular resistance $($ SVR $)>700$ dyn $\cdot \mathrm{s} \cdot \mathrm{cm}^{-5}$ ) during weaning from CPB and in the post-CPB period adrenaline, dobutamine, and noradrenaline were given when necessary. Glyceryl trinitrate or nifedipine were given when ST-segment analysis indicated ischaemia or filling pressures (PCWP, CVP) were $>15 \mathrm{~mm} \mathrm{Hg}$. All patients' lungs were mechanically ventilated for at least $5 \mathrm{~h}$ after CPB $\left(\mathrm{PaO}_{2}\right.$ was kept between 100 and 150 torr $(3.3$ and $20.0 \mathrm{kPa})$ and $\mathrm{PaCO}_{2}$ between 38 and 45 torr $(5 \cdot 0$ and $6.0 \mathrm{kPa}))$.

MEASURED VARIABLES AND DATA POINTS

MAP and heart rate (HR) were measured continuously. Additionally, all patients were monitored by means of a pulmonary artery catheter.
ST segment changes were analysed serially (Sirecust 1280, Siemens, Erlangen, Germany). Records of leads II and V5 were analysed by physicians who were blinded to the grouping of the patients. Ischaemia was defined as horizontal or down-sloping ST segment of at least $0 \cdot 1 \mathrm{mV}$, which extended at least $80 \mathrm{~ms}$ beyond the $\mathrm{J}$ point of the QRS complex, and/or as an elevation of $>0.2 \mathrm{mV}$ at the $\mathrm{J}$ point lasting for at least $1 \mathrm{~min} .{ }^{20}$ Myocardial infarction was defined by electrocardiographic (ECG) strip chart (occurrence of new $Q$ waves or a deepened $Q$ wave of one-third of the QRS height and $>0.04 \mathrm{~s}$ ) and increasing CKMB activity (normal < $12 \mathrm{U} / \mathrm{l})$. ECG strip charts were always interpreted by physicians who were blinded to the grouping of the patients.

Activities of creatine kinase isoenzyme MB (CKMB) (Boehringer Mannheim, Germany) measured with a Hitachi 717 analyser (normal value $<12 \mathrm{U} / \mathrm{l}$ ), plasma concentration of cardiac troponin $\mathrm{T}(\mathrm{TnT})$ measured with a commercial monoclonal-monoclonal, double antibody, one step sandwich enzyme immunoassay (ELISA) (Boehringer Mannheim ${ }^{7}$; normal value $<0.1 \mu \mathrm{g} / \mathrm{l}$ ), and the isoenzyme $\mathrm{BB}$ of the glycogen phosphorylase (GPBB) measured with a commercial, standardised enzyme-linked immunosorbent assay for the determination of human GPBB using two murine monoclonal antibodies $^{21}$ (Laboserv, Giessen, Germany) (normal value: none detected or $<5 \mathrm{ng} / \mathrm{ml}^{22}$ ) were measured in central venous blood samples. All measurements were carried out before start of infusion (baseline values), after weaning off $\mathrm{CPB}$, at the end of surgery, $5 \mathrm{~h}$ after $\mathrm{CPB}$, and on the first and third postoperative days. We used the following formula to correct the volume for all markers of ischaemia ${ }^{23}$ :

$$
\text { correction factor: } \frac{\text { phct }_{\text {ii }}}{\text { phct }_{\text {io }}}
$$

where phct $=$ plasma haematocrit $(100 \%-$ hct $\%)$, to = value at baseline, and $\mathrm{ti}=$ value at the time of sampling.

\section{STATISTICAL ANALYSIS}

All variables are expressed as mean (SD). Demographic data and outcome data (for example, number of patients who needed inotropic support) were tested using the chi-

Table 4 Haemodynamic changes in the four groups

\begin{tabular}{|c|c|c|c|c|c|c|c|}
\hline \multirow[b]{2}{*}{ Variable } & \multirow[b]{2}{*}{ Baseline } & \multirow[b]{2}{*}{ Before CPB } & \multirow[b]{2}{*}{ After CPB } & \multirow[b]{2}{*}{ End of surgery } & \multirow[b]{2}{*}{$5 \mathrm{~h}$ after $C P B$} & \multicolumn{2}{|c|}{ Postoperative day } \\
\hline & & & & & & 1st day & 3rd day \\
\hline $\begin{array}{l}\text { MAP (mm Hg): } \\
\text { Clonidine } \\
\text { Enoximone } \\
\text { Enalaprilat } \\
\text { Control }\end{array}$ & $\begin{array}{l}82 \cdot 9(5 \cdot 5) \\
84 \cdot 1(6 \cdot 1) \\
82 \cdot 3(8 \cdot 4) \\
82 \cdot 8(4 \cdot 8)\end{array}$ & $\begin{array}{l}78 \cdot 1(7 \cdot 7) \\
79 \cdot 9(8 \cdot 4) \\
76 \cdot 7(7 \cdot 1) \\
84 \cdot 4(10 \cdot 1)\end{array}$ & $\begin{array}{l}69 \cdot 0(9 \cdot 6) \\
78 \cdot 4(9 \cdot 4) \\
73 \cdot 2(8 \cdot 0) \\
77 \cdot 5(7 \cdot 8)\end{array}$ & $\begin{array}{l}81 \cdot 1(7 \cdot 0) \\
86 \cdot 5(8 \cdot 1) \\
77 \cdot 7(8 \cdot 1) \\
83.3(7 \cdot 9)\end{array}$ & $\begin{array}{l}91 \cdot 1(11 \cdot 0) \\
90 \cdot 1(11 \cdot 1) \\
83 \cdot 1(10 \cdot 8) \\
87 \cdot 1(9 \cdot 5)\end{array}$ & $\begin{array}{l}87 \cdot 3(6 \cdot 9) \\
89 \cdot 1(8 \cdot 1) \\
84 \cdot 9(10 \cdot 0) \\
85 \cdot 9(8 \cdot 9)\end{array}$ & $\begin{array}{l}81 \cdot 0(7 \cdot 6) \\
80 \cdot 1(6 \cdot 1) \\
75 \cdot 9(9 \cdot 6) \\
81.0(8 \cdot 5)\end{array}$ \\
\hline $\begin{array}{l}\text { HR (min-1): } \\
\text { Clonidine } \\
\text { Enoximone } \\
\text { Enalaprilat } \\
\text { Control }\end{array}$ & $\begin{array}{l}69 \cdot 6(5 \cdot 3) \\
69 \cdot 8(8 \cdot 3) \\
71.9(8.6) \\
66 \cdot 7(8 \cdot 5)\end{array}$ & $\begin{array}{l}60 \cdot 4(7 \cdot 9)^{\star} \\
74 \cdot 3(8 \cdot 9) \\
76 \cdot 2(9 \cdot 2) \\
69 \cdot 2(8 \cdot 4)\end{array}$ & $\begin{array}{l}90 \cdot 1(10 \cdot 0) \\
89 \cdot 1(8 \cdot 8) \\
91 \cdot 6(9 \cdot 9) \\
87 \cdot 2(10 \cdot 1)\end{array}$ & $\begin{array}{l}90 \cdot 2(11 \cdot 2) \\
91.5(10 \cdot 1) \\
93.3(9 \cdot 7) \\
92.3(9 \cdot 7)\end{array}$ & $\begin{array}{c}89.9(11 \cdot 1) \\
94 \cdot 0(11 \cdot 0) \\
95.5(8.3) \\
100 \cdot 1(8 \cdot 3)\end{array}$ & $\begin{array}{l}91 \cdot 5(12 \cdot 8) \\
94 \cdot 5(10 \cdot 0) \\
91.9(9.3) \\
94 \cdot 1(10 \cdot 1)\end{array}$ & $\begin{array}{l}85 \cdot 4(8.9) \\
87 \cdot 8(9 \cdot 0) \\
90 \cdot 2(8.9) \\
91 \cdot 1(7 \cdot 5)\end{array}$ \\
\hline $\begin{array}{l}\mathrm{CI}\left(1 \cdot \mathrm{min}^{-1} \cdot \mathrm{m}^{-2}\right): \\
\text { Clonidine } \\
\text { Enoximone } \\
\text { Enalaprilat } \\
\text { Control }\end{array}$ & $\begin{array}{l}2.78(0.2) \\
2.51(0.3) \\
2.69(0.3) \\
2.59(0.2)\end{array}$ & $\begin{array}{l}2.39(0.2)^{\star} \\
3.19(0.3) \dagger^{\star} \\
2.81(0.3) \\
2.41(0.2)\end{array}$ & $\begin{array}{l}3 \cdot 10(0 \cdot 3) \\
3 \cdot 01(0 \cdot 4) \\
3 \cdot 11(0 \cdot 2) \\
2 \cdot 80(0 \cdot 3)\end{array}$ & $\begin{array}{l}2.90(0.4) \\
2.77(0.3) \\
2.80(0.2) \\
2.41(0.3)\end{array}$ & $\begin{array}{l}2.89(0.4) \\
2.89(0.3) \\
2.81(0.4) \\
2.70(0.3)\end{array}$ & $\begin{array}{l}3.00(0.4) \\
3.19(0.3) \\
3.21(0.3) \\
2.98(0.3)\end{array}$ & $\bar{z}$ \\
\hline
\end{tabular}

MAP, mean arterial blood pressure; HR, heart rate; CI, cardiac index; CPB, cardiopulmonary bypass; ${ }^{\star} \mathrm{P}<0.05$ compared with the other groups; $\nmid \mathrm{P}<0.05$ compared with baseline value. 


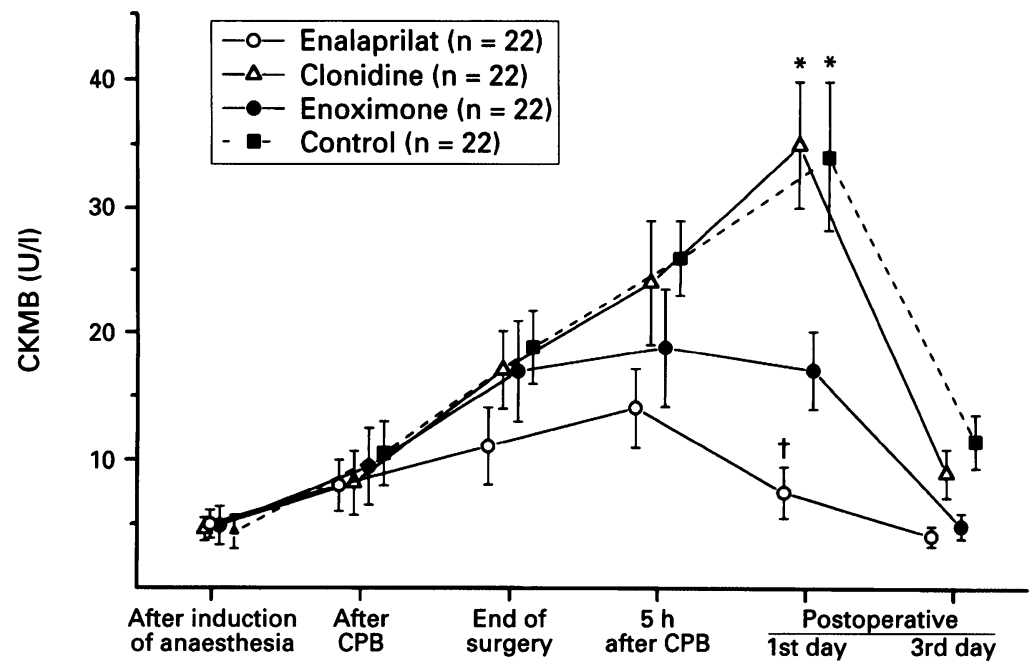

Figure 1 Plasma concentrations of creatine kinase isoenzyme $B B$ (CKMB) (mean $(S D)) .{ }^{\star} P<0.05$ versus enoximone and enalprilat group, $+P<0.05$ lowest value.

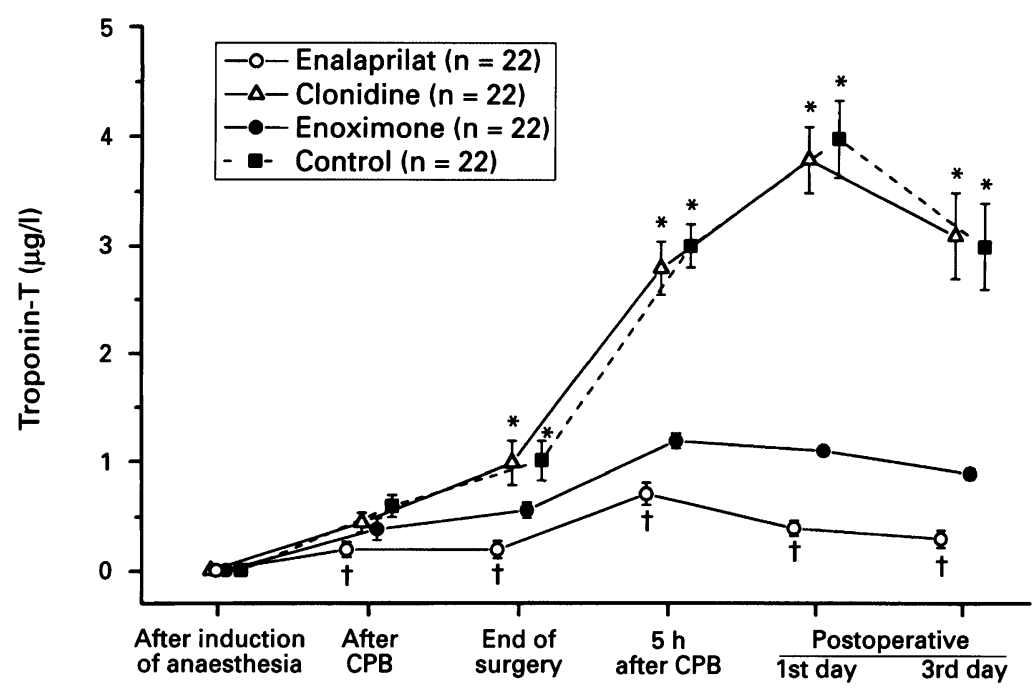

Figure 2 Changes in plasma concentrations of troponin $T(T n T)$ (mean (SD)). $\star P<0.05$ versus the other groups, $+P<0.05$ lowest value.

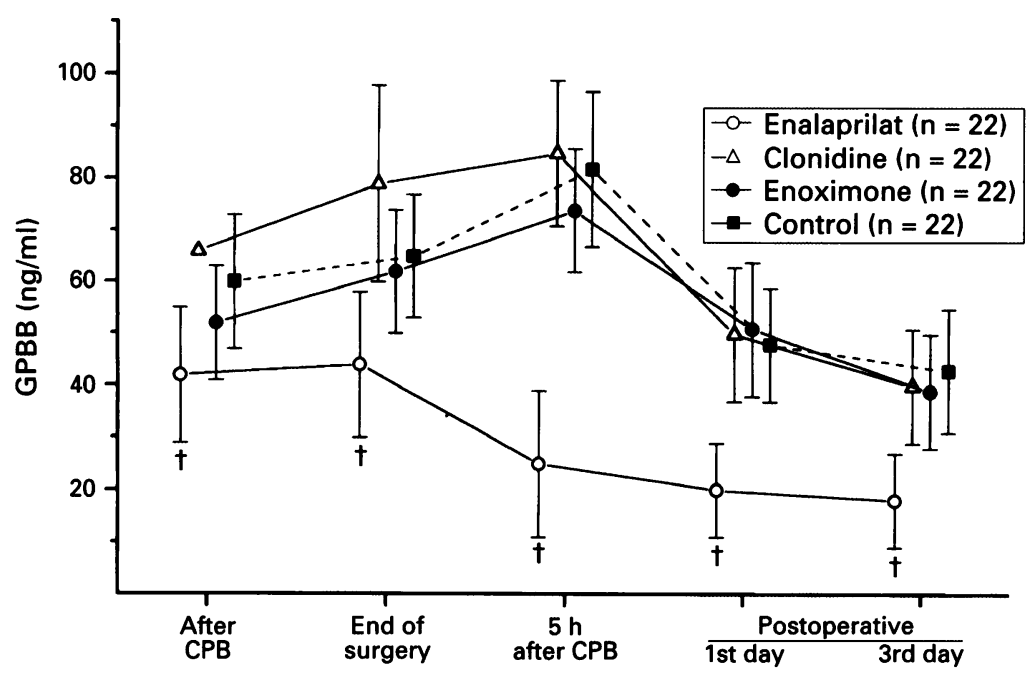

Figure 3 Changes in plasma concentrations of glycogen phophorylase BB (GPBB) in the Figure 3 Changes in plasma concentrations of glycogen phophorylase $B B$ (
postbypass and postoperative period (mean (SD)). $+P<0.05$ lowest value.

squared procedure and $t$ test. One and two factorial analyses of variance (ANOVA, MANOVA) with repeated measurements (followed by the Scheffe test) were used to determine the effects of group, time, and group-time interaction for each measured variable. $P$ values $<0.05$ were regarded as statistically significant.

\section{Results}

The groups did not differ with regard to demographic and intraoperative data (table 1). The test drug was given for $70 \mathrm{~min}$ to $95 \mathrm{~min}$, with no significant differences in duration between the groups. Two of the clonidine (9\%) and two of the control patients $(9 \%)$ had myocardial infarction (diagnosed from the ECG and an increase in CKMB activity). Pacing was necessary significantly more often in the clonidine group $(n=9)$ than in the other patients (table 1). More patients in the clonidine group than in the other pre-treated groups needed inotropic support (adrenaline, dobutamine) and vasodilators (glyceryl trinitrate) after being taken off the bypass $(P<0.05)$ (table 2). Similar numbers of patients in the clonidine and the control groups had ST-segment changes (table 3). ST segment changes were least common in the enalaprilat-treated patients $(P<0.01)$. All patients were transferred to a normal ward by the second day and none of the patients died during the study period. All patients were doing well (stable haemodynamics, no ECG changes) when they were discharged from hospital.

Infusion of all three substances produced similar reductions in MAP (table 4). HR decreased in the clonidine group (from 69.6 $(5 \cdot 3)$ to $\left.60.4(7 \cdot 9) \mathrm{min}^{-1}\right)$, whereas HR in the other groups remained almost unchanged during the infusion period (table 4). CI was reduced only in the clonidine patients (from $2.78(0.2)$ to $2.39(0.2) 1 \cdot \mathrm{min}^{-1} \cdot \mathrm{m}^{-2}$ ) and increased in the enoximone patients (from $2.51(0.3)$ to $3.19(0.3) 1 \cdot \mathrm{min}^{-1} \cdot \mathrm{m}^{-2}$ ) $(P<0.05)$ (table 4).

CKMB activity was similar in all four groups before and after CPB as well at the end of surgery and $5 \mathrm{~h}$ after CPB (fig 1). On the first postoperative day, CKMB was significantly higher in the clonidine $(35 \cdot 1(4.9) \mathrm{U} / \mathrm{l})$ and the control group $(34.2(5 \cdot 8) \mathrm{U} / \mathrm{l})$ than in the enoximone $(17 \cdot 1(3 \cdot 1) \mathrm{U} / \mathrm{l})$ and enalaprilat patients $(7.5(2.3) \mathrm{U} / \mathrm{l}, \mathrm{P}<0.001)$.

Baseline values of plasma TnT were normal in all the groups $(<0 \cdot 1 \mu \mathrm{g} / \mathrm{l})$; there were significant differerences between the groups after CPB (fig 2). At the end of surgery, TnT had increased most in the clonidine (from 0.01 $(0.04)$ to $0.99(0.2) \mu \mathrm{g} / \mathrm{l})$ and the control groups (from $0.01(0.01)$ to $1.01(0.18) \mu \mathrm{g} / \mathrm{l})$. In the group pretreated with clonidine, plasma TnT concentration increased significantly in the postoperative period, with a peak increase of $3.80(0.3) \mu \mathrm{g} / 1$ on the first postoperative day. In the control patients, it increased significantly from baseline values to $3.99(0.35)$ $\mu \mathrm{g} / \mathrm{l}$. In the groups treated with enoximone and enalaprilat, $\operatorname{TnT}$ increased only slightly (enoximone from $0.01(0.01) \mu \mathrm{g} / 1$ to a peak of $1.19(0 \cdot 1) \mu \mathrm{g} / 1$; with the enalaprilat group showing the lowest increase (from 0.01 $(0 \cdot 010) \mu \mathrm{g} / 1$ to a peak of $0.71(0 \cdot 1) \mu \mathrm{g} / 1$ : 
$P<0.001)$ compared with the other groups.

Starting from comparable baseline values $(<1 \mathrm{ng} / \mathrm{ml})$, GPBB plasma concentrations after CPB did not differ among the treated patients (fig 3). In the enalaprilat group they remained significantly lower during the entire postbypass and postoperative period (peak 44 (13) $\mathrm{ng} / \mathrm{ml}$ at the end of surgery) than in the other groups $(P<0.01)$. Plasma concentrations of GPBB were similar in the clonidinetreated patients (peak 85 (14) $\mathrm{ng} / \mathrm{ml} 5 \mathrm{~h}$ after $\mathrm{CPB}$ ) and the control group (peak 82 (15) $\mathrm{ng} / \mathrm{ml})$.

\section{Discussion}

Several substances have been claimed to have anti-ischaemic effects in patients undergoing cardiac surgery. ${ }^{15-17}$ The beneficial action of the centrally acting $\alpha_{2}$ adrenoceptor agonist clonidine was attributed to a reduction in sympathomimetic outflow. In an experimental setting, clonidine was shown to be of benefit in avoiding myocardial ischaemia. ${ }^{24}$ In patients undergoing $\mathrm{CABG}$, oral pretreatment with clonidine $(5 \mu \mathrm{g} / \mathrm{kg})$ reduced the incidence of ischaemic ST segment changes compared with an untreated control group. ${ }^{17}$ Clonidine did not provide the myocardium of our patients with much protection from ischaemia: ST segment alterations indicating ischaemia were most often seen in these patients and CKMB plasma concentrations increased after CPB, which was taken to indicate myocardial issue damage. ${ }^{25}$ Serial measurements of two other more sensitive markers of myocardial cell damage, TnT and GPBB, were similar in the clonidine and control groups. The increases in TnT plasma concentrations of our control (and clonidine) patients in the postbypass and postoperative periods were similar to those reported by Mair et al who found an increase of up to $3.5 \mathrm{U} / 1$ in patients with an "uncomplicated" course after CPB and of more than 3.5 $\mathrm{U} / 1$ in patients showing ST-segment changes. ${ }^{4}$ Hofmann et al reported on three patients undergoing $\mathrm{CABG}$ and found a plasma concentration of GPBB of about $50 \mathrm{ng} / \mathrm{ml}$ after release of the cross-clamp (that is, the beginning of reperfusion), ${ }^{21}$ which accords with the data of our clonidine, control, and enoximone groups in the postbypass period.

The PDE-III inhibitor enoximone may influence myocardial ischaemia either by its (direct) effects on the cAMP system or (indirectly) by improving coronary (micro) perfusion. In patients in whom ventricular pacing was performed, enoximone increased the angina threshold while the left ventricular stroke work index was maintained. ${ }^{18}$ The question whether this effect was due only to reduction in wall stress secondary to vascular vasodilatation, was studied by Schlepper et al. ${ }^{26}$ Intracoronary administration of enoximone $(0.075 \mathrm{mg} / \mathrm{kg})$ into a stenosed coronary vascular bed produced no noticeable systemic haemodynamic effects, serum concentrations were below therapeutic concentration but anti-ischaemic effects were still seen. In our study, both new markers of minor myocardial cell damage were less increased in the enoximine group than in the untreated control group after CPB and later in the postoperative period, which seems to indicate less postbypass myocardial cell damage. These beneficial effects of enoximone may also result from its endocrinological consequences (for example, decrease in plasma vasopressin and decrease in plasma and myocardial catecholamines)..$^{27}$

The renin angiotensin system (RAS) seems to play an important part in cardiovascular homoeostasis ${ }^{28}$ and the benefit of interruption of the RAS by ACE inhibitors during perioperative stress has already been demonstrated. ${ }^{29}$ Protective effects of ACE inhibitors after myocardial infarction have been convincingly demonstrated. ${ }^{30}$ In patients with myocardial ischaemia showing abnormal myocardial lactate metabolism, enalaprilat relieved myocardial ischaemia. ${ }^{31}$ ACE inhibitors also had cardioprotective effects when they were given before ischaemia. In an experimental setting when myocardial ischaemia was induced by coronary occlusion, enalapril resulted in a preservation of myocardial tissue. ${ }^{19}$ When intravenous enalaprilat was given to our patients in the pre-bypass period it significantly reduced ischaemia-related sequelae in the myocardium. ST segment changes were least common and changes in both new markers of (minor) myocardial cell injury (TnT, GPBB) were smallest during the entire postbypass and postoperative period in the group treated with enaliprilat. The mechanisms of the beneficial effects of ACE inhibitors in this situation has not yet been clarified. ACE inhibitors act not only by blocking systemic angiotensin converting enzyme but also by inhibiting tissue ACE. ${ }^{32}$ Stimulation of prostacyclin synthesis, increased endothelial production of nitric oxide, and limitation of endothelin production may also contribute to their cardioprotective effects. ${ }^{28}$ The beneficial effects of enalaprilat in our study contrast with results in an experimental setting. ${ }^{33}$ When various ACE inhibitors were given $10 \mathrm{~min}$ before a $25 \mathrm{~min}$ period of global ischaemia and during a $30 \mathrm{~min}$ period of reperfusion in the isolated rat heart, an improvement in post-ischaemic contractile function and a reduction in cell death was seen only in the groups that had captopril and zofenopril-sulphhydryl added; enalaprilat was not cardioprotective in high concentrations. The authors assumed that only sulphhydryl-containing ACE inhibitors (not enalaprilat) are effective in limiting ischaemic myocardial tissue damage.

One major problem is that the optimal doses for myocardial protection of the infused substances are not definitely known. We gave $0.05 \mu \mathrm{g} \cdot \mathrm{kg}^{-1} \cdot \mathrm{min}^{-1}$ of clonidine continuously by intravenous infusion, a total dose of 307 (26) $\mu \mathrm{g}$. In a study aimed at reducing intraoperative stress, Kulka et al used 2 to $6 \mu \mathrm{g} / \mathrm{kg}$ intravenously, ${ }^{34}$ which is comparable to the dosage in our study. Others used oral clonidine (for example, $5 \mu \mathrm{g} / \mathrm{kg} 90 \mathrm{~min}$ before surgery ${ }^{17}$ ), which gives widely varying plasma concentrations. Our dose of enoximone was 
also commonly given by others and does not appear to have detrimental haemodynamic effects. ${ }^{35}$ Doses of single bolus injection of enalaprilat vary widely, from $0.625 \mathrm{mg}$ to $40 \mathrm{mg} .{ }^{36}$ Doses of $0.2 \mathrm{mg}$ to $1.2 \mathrm{mg}$ in patients with myocardial infarction almost completely suppressed plasma angiotensin enzyme activity. ${ }^{37}$

Although all the drugs used in this study have long pharmacological half lives, we gave them by continuous intravenous administration because this route is associated with fewer negative haemodynamic sequelae. Data from the present study do not show whether different plasma concentrations of the three drugs at the end of the ischaemic period (in the reperfusion period after release of aortic cross-clamp) influenced myocardial cell damage. Because all of them have a half-life greater than $60 \mathrm{~min}$, all seem to be present in the reperfusion period and thus may have influenced postCPB myocardial ischaemia in this way as well.

It is difficult to compare the results of our study with those of other studies focusing on myocardial ischaemia in cardiac surgery patients because of the widely varying study conditions. Different methods of myocardial preservation (for example, different cardioplegic solutions), different patient populations (for example, valve versus CABG patients, stable versus unstable angina), different degrees of hypothermia, varying periods of aortic cross-clamping, and different technique of anaesthesia may influence the degree of ischaemia-related myocardial cell damage.

It was not the aim of the present study to determine whether drugs can help to improve outcome in cardiac surgery. This would require comprehensive multicentre studies. However, the importance of intraoperative ischaemia in these patients has recently been emphasised..$^{38}$ According to Mangano et al the positive predictive value of intraoperative ischaemia was better than that of postoperative ischaemia $(33 \% v 26 \%)$ as was the specificity $(79 \% \quad v 64 \%)^{39}$ - thus intraoperative ischaemia may indicate a higher risk than postoperative ischaemia. The present study was performed in elective coronary artery bypass grafting. The beneficial cardioprotective effects may be of particular interest in emergency or complicated surgical procedures with expected prolonged ischaemic periods and patients at higher risk of myocardial ischaemia.

In summary, one major therapeutic aim in cardiac surgery should certainly be the prevention of myocardial ischaemia. New markers of myocardial ischaemia such as cardiac troponin (TnT) and the isoenzyme BB of the glycogen phosphorylase (GPBB) give us a better way of monitoring our attempts at cardioprotection. Intravenous enalaprilat given in the preischaemic period resulted in the smallest overall increase in these markers of ischaemia after $\mathrm{CPB}$, whereas clonidine had no benefical cardioprotective effects and cannot be recommended for this purpose in cardiac surgery. Our results should prompt further investigations to assess the exact role of ACE inhibitors in reducing myocardial ischaemia in cardiac surgery patients.

1 Slogoff S, Keats AS. Further observations on perioperative myocardial ischemia. Anesthesiology 1986;65:539-42.

2 Balderman SC, Bhayana JN, Steinbach JJ. Perioperative myocardial infarction: a diagnostic dilemma. Ann Thorac Surg 1980;30:370-7.

3 Haagensen R, Steen PA. Perioperative moycardial infarction. $B r \mathcal{F}$ Anaesth 1988;61:24-37.

4 Mair PM, Mair J, Seibt I, Furtwaingler W, Waldenberger $\mathrm{F}$, Puschendorf $\mathrm{B}$, et al. Cardiac troponin $\mathrm{T}$ : a new marker of myocardial tissue damage in bypass surgery. $f$ Cardiothorac Vasc Surg 1993;7:674-8.

5 Katus HA, Schoeppenthau M, Tanzeem A, Bauer HG, Saggau W, Diederich KW, et al. Noninvasive assessment of perioperative myocardial cell damage by circulating cardiac troponin T. Br Heart $\mathcal{f}$ 1991;65:259-64.

6 Mair J, Artner DE, Lechleitner P, Smist J, Wagner I, Dienstl F, et al. Cardiac troponin T in diagnosis of acute myocardial infarction. Clin Chem 1991;37:845-52.

7 Katus HA, Looser S, Hallmeier K, Remppis A, Scheffolf T, Borgya $A$, et al. Development and in vitro characterization of a new immunoassay of cardiac troponin T. Clin tion of a new immuno $1992 ; 38: 386-93$.

8 Adams JE, Abendschein DR, Jaffe AS. Biochemical markers of myocardial injury: is MB creatine kinase the choice ef of myocardial injury: is MB creatine ki

9 Gerhardt W, Katus HA, Ravkilde J, Hammm C, Jorgensen PJ, Peheim E, et al. S-troponin T in suspected ischemic myocardial injury compared with mass and catalytic concentrations of S-creatinine kinase isoenzyme MB. Clin Chem 1991;37:1405-11.

10 Mair J, Puschendorf B, Smidt J, Lechleitner P, Dients F, Noll $F$, et al. Early release of glycogen phosphorylase in patients with unstable angina and transient ST-T alterations. Br Heart $\mathcal{f} 1994 ; 72: 125-7$.

11 Entman ML, Bornet EP, Vanwickle WB, Goldstein MA Schwartz A. Association of glycogenolysis with cardiac sarcoplasmatic reticulum: effects of glycogen depletion deoxycholate solubilization and cardiac ischemia: evidence for a phosphorylase kinase membrane complex. $f$ Mol Cell Cardiol 1977;9:515-28.

12 Michael LH, Hunt JR, Weilbacher D, Perryman MB, Roberts R, Lewis RM. Creatine kinase and phosphoryase in cardiac lymph: coronary occlusion and reperfusion. Am ₹ Physiol 1995;248:H350-9.

13 Rabitzsch G, Mair J, Lechleitner P, Noll F, Hoffmann U, Krause EG, et al. Isoenzyme BB of glycogen phosphorylase $b$ and myocardial infarction. Lancet 1993;241: 1032-3.

14 Davies ME, Jones CJH, Feneck RO, Walesby RK. The effects of intravenous nitroglycerin and isosorbide dinitrate on hemodynamics and myocardial metabolism. $f$ trate on hemodynamics and myocardial
Cardiothorac Vasc Anesth 1989;3:712-9.

15 Seitelberger R, Zwölfer W, Binder T, Huber S, Peschl F Spatt J, et al. Infusion of nifedipine after coronary bypass Spatt J, et al. Infusion of nifedipine after coronary bypass grafting decreases the incidence of early postoperative
myocardial ischemia. Ann Thorac Surg 1990;49:61-8.

myocardial ischemia. Ann Thorac Surg 1990;49:61-8.
16 Bolling SF, Groh MA, Mattson AM, Gringae RA, Gallagher K. Acadesine (AICA-Riboside) improves postischemic cardiac recovery. Ann Thorac Surg 1992;54: 93-9.

17 Dorman BH, Zucker JR, Verrier ED, Gartman DM, Slachman FN. Clonidine improves perioperative myocardial ischemia, reduces anesthetic requirement, and alters hemodynamic parameters in patients undergoing coronary artery bypass surgery. $\mathcal{f}$ Cardiothorac Vasc Anesth 1992;6:344-59.

18 Thormann J, Kremer P, Mitrovic V: Effects of enoximone in coronary artery disease: increased pump function, improved ventricular wall motion and abolition of pacin induced myocardial ischemia. 7 Appl Cardiol 1989;4: $152-67$.

19 Hock CE, Ribeiro LG, Lefer AM. Preservation of ischemic myocardium by a new converting enzyme inhibitor, maprilic acid in acute myocardial infarction. Am Hear f 1985;109:222-8.

20 Smith RC, Leung JM, Mangano DT, the SPJ Research Group. Postoperative myocardial ischemia in patients Group. Postoperative myocardial ischemia in patients
undergoing coronary artery bypass graft surgery. undergoing coronary artery
Anesthesiology 1991;74:464-73.

21 Hofmann U, Rabitzsch, Lüster K, Handschack W, Noll F, Krause EG. Immunenzymometric assay for the heart specific glycogen phosphorylase BB in humans using specific glycogen phosphorylase BB in humans using
monoclonal antibodies. Biomed Biochem Acta 1989;48: 132-6.

22 Rabitzsch G, Noll F, Hofmann U, Krause EG, Armbruster FP. Basal concentration of the isoenzyme BB of the glycogen phosphorylase in human blood. Clin Chim Acta 1993;214:109-11.

23 Feindt P, Volkmer I, Seyffert UT, Haack H. The role of protein $\mathrm{C}$ as an inhibitor of blood clotting during extracorporeal circulation. Thorac Cardiovasc Surgeon 1991;39. 338-43.

24 Heusch G, Schipke J, Thamer V. Clonidine prevents the sympathetic initiation and aggravation of poststenotic myocardial ischemia $y$ Cardiovasc Pharmacol 1985;7: myocardial

25 Lee TH, Goldman L. Serum enzyme assays in the diagnosis of acute myocardial infarction. Ann Int Med 1987;105: 221-33.

26 Schlepper M, Thorman J, Mitrovic V. Cardiovascular 
effects of forskolin and phosphodiesterase-III inhibitors. Bas Res Cardiol 1989;84(suppl 1):197-212.

27 Mitrovic V, Thorman J, Neuzner J, Bahavar H, Volz M, Dieterich HA, et al. Hemodynamic, antiischemic, and neurohumoral effects of enoximone in patients with coronary artery disease. Am Heart f 1989;117:106-11.

28 Colson P. Angiotensin-converting enzyme inhibitors in cardiovascular anesthesia. F Cardiothorac Vasc Anesth 1993; 7:734-42.

29 Murphy JD, Vaughan RS, Rosen M. Intravenous enalaprilat and autonomic reflexes. Anaesthesia 1989;44:816-21.

30 Thürmann P, Rietbrock N. Current concepts: converting enzyme inhibitors in coronary artery disease. Clin Invest 1992;70:70-6.

31 Chatterjee K, Marco TD. Systemic and coronary hemodynamics and pharmacokinetics of enalapril and enalaprilat in congestive heart failure. Drugs 1990;39(suppl 4): in cons.

32 Dzau VJ. Circulating versus local renin-angiotensin in cardiovascular homeostasis. Circulation 1988;77(suppl I): 4-13.

33 Grover GJ, Sleph Pb, Dzoncyk S, Wang P, Fung W, Tobias $\mathrm{D}$, et al. Effect of different angiotensin-converting enzyme (ACE) inhibitors on ischemic related rat hearts: relationship between cardiac ACE inhibition and cardioprotection. F Pharmacol Exp Ther 1991;257:919-29.

34 Kulka PJ, Tryba M, Zenz M. Dose-response effects of intravenous clonidine on stress response during induction of anesthesia in coronary artery bypass graft patients. Anesth Analg 1995;80:263-8.

35 Weber KT, Janicki JS, Jain MC. Enoximone (MDL $17,043)$, a phosphodiesterase inhibitor, in the treatment of advanced, unstable chronic heart failure. 7 Heart Transplant 1986;5:105-12.

36 Sigurdsson A, Held P, Andersson G, Swedberg K. Enalaprilat in acute myocardial infarction. tolerability and effects on the renin-angiotensin system. Int $f$ Cardiol 1991;33:115-24.

37 DiPette DJ, Ferraro JC, Evans RR. Enalaprilat, an intravenous angiotensin-converting enzyme inhibitor, in hypertensive crisis. Clin Pharmacol Ther 1995;38: hyp-204.

38 Thompson IR. Con: Intraoperative myocardial ischemia is not benign. $₹$ Cardiothorac Vasc Anesth 1994;8:593-5.

39 Mangano DT, Hollenberg M, Fegert G. Perioperative myocardial ischemia in patients undergoing non-cardiac myocardial ischemia in patients undergoing non-cardiac
surgery-I. Incidence and severity during the 4 day perioperative period. Am $\mathcal{f}$ Coll Cardiol 1991;17:843-50.

\section{IMAGES IN CARDIOLOGY}

\section{D construction from spiral CT scanning of pericardial calcification}

(A)

(B)

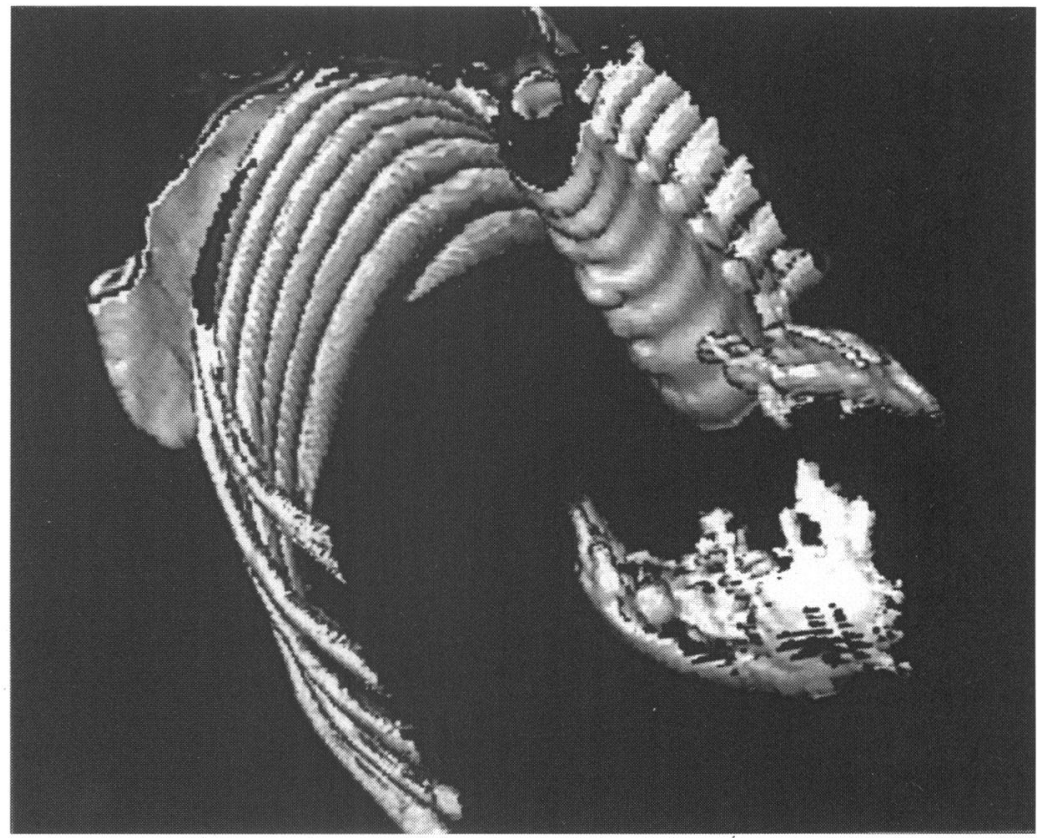

A 63 year old woman presented with tiredness and ankle swelling and was found to have systemic venous congestion. Her anterior-posterior and lateral (A) chest $x$ rays showed a rim of calcification mainly affecting the inferior part of the pericardium and the diagnosis of calcific constrictive pericarditis was subsequently made. Her condition gradually worsened despite treatment with diuretics, and surgery was considered. A preoperative spiral com- puted tomograph (B) with a 3D reconstruction shows that the pericardial calcification is more extensive than suggested by the $x$ rays. Calcification involved the pulmonary arteries and the whole of the inferior and posterior parts of the pericardium. This information is helpful to the surgeons in their approaches to pericardiectomy. 